\title{
Antitrypanosomal Activity of Flavonoid Extracted from Ximenia Americana Stem Bark
}

\author{
Maikai V.A \\ College of Agriculture and Animal Science, Ahmadu Bello University \\ P.M.B.2134, Mando - Kaduna, Nigeria \\ E-mail: ambrosev2003@yahoo.com
}

\begin{abstract}
The resurgence of Human African Trypanosomosis and Animal African Trypanosomosis in the latter part of the $20^{\text {th }}$ century after it had been brought largely under control in the 1960 has been alarming. Methanolic extract of stem bark of Ximennia americana were partitioned to obtain their major phytochemical fractions, these were evaluated for their in vitro and in vivo antitrypanosomal activities against Trypanosoma congolense. The Flavonoid fraction significantly $(\mathrm{P}<0.05)$ inhibited the motility of the blood stream forms with $10 \mathrm{mg} / \mathrm{ml}$. However, when the infected mice were treated at 5,10 and $25 \mathrm{mg} / \mathrm{ml}$ of the flavonoid fractions, there was a suppression of the growth of the parasites in a dose dependent manner with the $25 \mathrm{mg} / \mathrm{ml}$ producing the maximum effect. The results further confirm the ethnopharmacological usage of Ximenia americana against Trypanosomosis.
\end{abstract}

Keyword: Flavonoid, Ximenia americana, Antitrypanosomal activity

\section{Introduction}

Trypanosomosis is a group of diseases affecting both man and animals. The disease is most important in cattle due to their grazing activity, but can cause serious losses in pigs, camels, goats and sheep. It has been estimated that 46 million cattle are exposed to the risk of contracting the disease and that the disease cost an estimated 1340 million USD per year (Croft, 1996), and that 3 million cattle die as a result, each year (Kristjanson et al., 1999; WHO, 2000). The currently available treatments are far from ideal, as the registered trypanocides are toxic, expensive administration procedures and old while the parasites have develop resistance (Gutteridge, 1985; Ndung'u et al., 1999; McDermott et al., 2000; Anene et al., 2001; Maikai et al., 2007). Any synthetic chemical / medicinal plant /natural product, that is able to delay, suppress the growth, completely prevent the growth or kill the parasites or have potentials to ameliorate anemia, a hall mark sign of trypanosomosis in mammals will equally delay or prevent the clinicopathological manifestation of the disease could be said to be an effective chemotherapeutic agent. One approach of protozoan chemotherapy relies in the testing of natural products for antitrypanosomal activity. Nature with its numerous plants is a potential source of new drugs since it contains countless quantity of molecules with a great variety of structures and pharmacological activities (Hoet et al., 2004). Plant products such as quinine, an alkaloid from Cinchona spp (Rubiaceace) and artemisinin, a sesquiterpene lactone from Artemisia annua (Asteraceae) are used to treat malaria. Flavonoids are a large group of polyphenolic compounds possessing a basic flavan nucleus with two aromatic rings (the A and the B rings) interconnected by a three carbon atom heterocyclic ring (the $\mathrm{C}$ ring). The most wide spread flavonoids contain a double bond between C-2 and C-3 $\left(\Delta^{2,3}\right)$ and a keto function at C-4 which is attached to ring B at C-2 (flavone) or at C-3 (isoflavone). Flavonoids have been known for a longtime to exert diverse biological effects including antibacterials, antioxidants, antitumor, antiviral, anti-inflammatory, antiallergic, vasodilatory actions both in animals and humans (Wang, 2000; Harborne and Williams, 2000). These antiprotozoal plant-derived compounds have been used as leads to develop semi synthetic drugs with better efficacy, safety, or pharmacokinetic profiles. Plant extracts could provide novel possibilities against trypanosomes (Freigburghaus et. al., 1996; Adewunmi et. al., 2001; Nok, 2002; Pizzolatti et. al., 2002; Atawodi et. al., 2003; Hoet et. al., 2004; Maikai et al., 2008a). The antitrypanosomal effect of stem bark extracts have earlier been reported (Maikai, 2010).

Herein the effect of a partially purified flavonoid extracted from stem bark of Ximenia americana is reported.

\section{Materials and methods}

\subsection{Collection of plant material}

Fresh stem bark of Ximenia americana was collected from Afaka village, $35 \mathrm{~km}$ to Kaduna and taken to Department of Biological Sciences, Ahmadu Bello University Zaria confirmed the identity of the plant with 
voucher No.1612. The stem bark was dried at room temperature before crushing into powder then stored in air tight container and kept at $4^{0} \mathrm{c}$ until needed.

\subsection{Plant extraction}

The extraction and fractionation of flavonoids from stem bark of Ximenia americana was carried out as described by Won et. al., (1980). Briefly, air-dried stem bark powdered material (500g) was successively extracted at room temperature using soxhlet extraction with petroleum ether $60-80^{\circ} \mathrm{c}$ to exhaustion. The petroleum ether portin was concentrated at room temperature to give a semi-oily mass of $(5.20 \mathrm{~g})$ which was coded "PXa". The defatted marc was exhaustively extracted at room temperature with methanol $(4 \mathrm{X} 300 \mathrm{ml})$ the combine methanolic extract was then successively partitioned with ether: water 1:1 $(3 \mathrm{X} 250 \mathrm{ml})$. The water portion was again partitioned with $\mathrm{n}$ butanol $(4 \mathrm{X} 350 \mathrm{ml})$. The butanolic portion was collected and partitioned with $1 \%$ potassium hydroxide $(3 \mathrm{X} 350 \mathrm{ml})$, the butanolic portion was collected and concentrated at room temperature to give the saponin fraction coded "SpXa". The potassium hydroxide portion was again partitioned with $2 \% \mathrm{HCl}$ : butanol 1:1 $(3 \mathrm{X} 300 \mathrm{ml})$. The butanol portion was collected in a porcelain dish and concentrated at room temperature to give the flavonoid fraction coded "FpXa".

\subsection{Animals}

Swiss albino mice (20-32g) aged 8- 12 weeks, bred in the College of Agriculture and Animal Science, Ahmadu Bello University, Mando Road Kaduna were used for the study. They were kept in clean plastic cages in a $12 \mathrm{~h}$ light /dark cycle with litter changed every week. They were fed with mice cubes specially prepared by ECWA feed Jos Plateau State Nigeria. They were watered ad lib. A standard protocol was observed in accordance with the Good Laboratory Practice (GLP) Regulations of the WHO (1998). The animal Laboratory care of (CCAC, 1993) was strictly followed.

\subsection{Phytochemical screening}

The stem bark extract was screened as described by Sofowora (1993), Trease and Evans (1989), and Harborne (1973).

\subsection{Parasites}

Stabilates of $T$. congolense (Nasarawa strain), were obtained from Nigeria Institute for Trypanosomiasis Research Vom, Plateau State Nigeria and passage into mice. The parasites were maintained in the mice by serial passage in mice.

\subsection{In vitro trypanocidal activity of Flavonoid and Saponninc extracts of stem bark of Ximenia americana}

Stock solutions of each extract were prepared in $0.5 \%$ Dimethylsulfoxide (DMSO). Other concentrations were made by dilution to 10 and $5 \mathrm{mg} / \mathrm{ml}$ respectively. Diminal ${ }^{\mathrm{R}}$ (standard drug) was similarly prepared at $200 \mu \mathrm{g} / \mathrm{ml}$ stock concentration and diluted to 100 and $50 \mu \mathrm{g} / \mathrm{ml} .200 \mu 1$ of the infected blood was placed in several 96 wells microtiter plates and incubated with $100 \mu \mathrm{l}$ of 20,10 and $5 \mathrm{mg} / \mathrm{ml}$ of each extract respectively and 200, 100 and $50 \mu \mathrm{g} / \mathrm{ml}$ of standard drug at $27^{\circ} \mathrm{c}$ in triplicate. As control, $200 \mu 1$ of infected blood was incubated with $100 \mu 1$ of $0.5 \%$ Dimethylsulfoxide. Microscopic observations of the parasites were performed every 5 minutes to check for death, motility or any morphological alterations of the parasites using X400 objective. Cessation or drop in motility of the parasites in extract-treated blood compared to that of parasite-loaded control blood without extract was taken as a measure of antitrypanosomal activity (Atawodi et al., 2003).

\subsection{In vivo experiment}

Following the in vitro studies, the flavonoid portion which showed high antitrypanosomal activity in vitro was used for in vivo evaluation. A total of thirty five mice were randomly grouped into five groups (A, B, C, D, E, F and G) of five mice each. Group A, B, C, D, E and F were infected with $10^{2} T$. congolense each. When parasites were detected, group B, C, D, E and F were intraperitonneally administered, $5,10,15$ and $25 \mathrm{mg} / \mathrm{kg}$ body weight flavonoid extract of Ximenia americana stem bark for 6 days and $3.5 \mathrm{mg} / \mathrm{kg}$ body weight

Diminal $^{\mathrm{R}}$ (single dose) respectively. Group A, infected and untreated was the control, while group G was not infected but treated with $25 \mathrm{mg} / \mathrm{kg}$ body weight with the flavonoid extract for six days intraperitoneally (to check for toxicity) of the flavonoid. Parasitemia was monitored on daily basis by obtaining blood from the pre-sterilized tail and determining the number of parasites microscopically at X400 magnification using method of (Herbert and Lumsden, 1976).

\subsection{Statistics}

The mean and standard deviation and the level of significance for the differences between means were computed by student's t test. 


\section{Results}

The in vitro result of the flavonoid extract of stem bark of Ximenia americana on the blood stream forms of Trypanosoma congolense significantly $(\mathrm{P}<0.05)$ immobilized the parasites or killing them at $10 \mathrm{mg} / \mathrm{ml}$ (Table 1$)$, when the mixtures were viewed under the microscope, compared, to the control which showed the blood streams forms of $T$. congolense active and motile after 2 hours of incubation with Dimethylsulfoxide (DMSO). To further confirm the in vitro effect of the extract, the mixtures were inoculated into apparently healthy mice showed them to be aparasitemic after 21 days monitoring period while the control (Dimethylsulfoxide (DSMO) and parasites incubated) and inoculated into healthy mice showed the mice to be parasitemic after 10 days of monitoring. Phytochemical screening was positive only for saponnins and flavonoids as shown (Table 2). The in vivo study was to obtain additional evidence of antitrypanosomal activity of the extract. In vivo results showed that $25 \mathrm{mg} / \mathrm{ml}$ dose significantly $(\mathrm{P}<0.05)$ appeared to be more effective in suppressing the multiplication or growth of the parasites when compared to the untreated group. In contrast, intraperitoneal injection of $3.5 \mathrm{mg} / \mathrm{kg}$ Diminal R completely cleared the parasites from circulation on day two post treatment. When compared to the untreated group, there was increase in parasitemia (Fig. 1), the flavonoid had some activity on the parasites, though the activity appeared to be dose dependent (Fig. 1) There was no changes in behavior, morbility and mortality observed among the group not infected but intraperitoneally administered $25 \mathrm{mg} / \mathrm{kg}$ flavonoid .

\section{Discussion}

In our preliminary screening using stem bark extract of Ximenia americana for antitrypanosomal activity against blood stream forms, the results showed that methanol extract had activity (Maikai et al., 2008a). In vitro system of screening plant extracts for activity against parasites is the fastest and reliable method of screening different types of plants; it also eliminates or reduces the use of experimental animals. Motility of parasites constitute a relatively reliable indicator of viability of most zooflagellate parasites (Peter et. al, 1976; Kaminsky, et al., 1996). Atawodi et al., (2003) reported that complete elimination of parasites or reduction in motility of parasites when compared to the control could be taken as indices of trypanocidal effect. Respiration of trypanosome parasite is obligatory for rhythmic flagella movement as well as for managing the energy reserve required for the synthesis of the variable surface glycoproteins. The inhibition of cellular and mitochondrial respiration by any chemotherapeutic agent will obviously compromise all the energy - dependent processes (Nok, 2002). This was confirmed by the microscopy of the cells, which showed an immediate cessation of flagella movement after incubation with the methanolic and flavonoid portion of the extract. The result indicated that the extracts eliminated the parasite in vitro which is similar with that reported (Freigburghaus et. al., 1996; Adewumi et al., 2001; Nok, 2002; Atawodi et al., 2003; Hoet, et. al., 2004; Maikai et al., 2008a) which showed that some medicinal plants had promising activity against trypanosomes. Though the concentration of the extracts were high $(20 \mathrm{mg} / \mathrm{ml})$ when compared to the concentration of the trypanocide $\left(\right.$ Diminal ${ }^{\mathrm{R}}$ ) which was $200 \mu \mathrm{g} / \mathrm{ml}$. Phytochemicals, in contrast to synthetic pharmaceuticals based upon single chemicals, may exert their effects through the additive or synergistic action of several chemical compounds acting at a single or multiple target sites associated with a physiological process (Kaufmann et al., 1999; Tyler, 1999).This suggests that the extracts were still crude and made of complex composition of chemicals compared to the standard drug which is a pure compound. Further purification of the extracts could lead to isolation of purer compounds with increased activity. The result is similar to (Raz, 1998; Camacho et al., 2000b; Tarus et al., 2002) who reported that flavonoids from flavone, flavonol, flavonone, isoflavone and chalcone subclasses had antitrypanosomal activity. Similarly, Tasdemir et al (2006) also reported that flavonoids were potent in vitro agents, but when administered in vivo significantly reduced the level of parasitemia, and did not completely clear the parasites. The flavonoid had no toxic effect on the animals, we had earlier reported (Maikai et al., 2008b) the toxicity effect of stem bark extract of Ximenia americana.The study completely agrees with the report of Tasdemir et al., (2006). Possible chemotherapeutic targets of the flavonoid could be the replicating forms of trypanosomes which are totally dependent on glycolysis for energy production (Opperdoes, 1987). The mitochondrial respiration of the long slender forms in the mammalian host is limited to oxidizing L-G3P mediated electron transport system composed of Glyceraldehyde 3 phosphate dehydrogenase (G3PDH) and cyanide insensitive and Salicyl hydroxamine acid (SHAM) - sensitive trypanosome alternative oxidase ubiquinol oxygen oxidoreductase (Hannae and Mitchel 1994). The inability of the flavonoid to completely clear the parasites in vivo coulb be that it failed to reach its target organ in sufficient concentration and duration to effect a cure or it could have a short half life making it unable to stay long enough to exert any effect on the parasites. Flavonoids are said to be absorbed into the plasma, however, the level of absorption, bioavailability and biological activity is highly dependent on the nature of the flavonoid. Bioavailability studies have shown that the circulating form of most flavonoids is as a conjugate (formed by deglycosylation, glucunodation, sulfation and methylation reactions 
mediated by a range of enzymes in the small intestine, liver and colon) which is then excreted into bile and urine (Williamson et al., 2005). The mode of flavonoid action against Trypanosome congolense is unclear in this study, however, it has been suggested that flavonoids did inhibit the influx of L- glutamine and myoinositol into infected erythrocytes (Kayser et al., 2003). Cowan (1999) suggested the mode of action to their ability to complex with extracellular and soluble proteins or disrupt membranes of the parasites, while Sepulveda - Boza and Cassels, (1996) suggested that many natural products exhibited their trypanocidal activity by virtue of their interference with the redox balance of the parasites acting either on the respiratory chain or on the cellular defenses against oxidative stress. Nok (2002) reported that azaanthraquinone was potentially active against $T$. congolense respiration. He suggested that the target of azaanthraquinone mediated killing of the parasite was associated to the CoQ redox site.

In conclusion, this work demonstrates that Ximenia americana did possesses some potentials for a chemical lead for a new trypanocidal drug. The flavonoid fraction showed a very promising in vitro activity against Trypanosoma congolense, it was able to suppress the growth of the parasite in vivo. The type of flavonoid responsible for the activity is however not known for now; more studies need to be carried out to identify the type of flavonoid. Probably if the flavonoid fraction is coupled with another agent in a cocktail its activity in vivo could be enhanced. Currently, studies is been carried out to determine the structure and type of flavonoid.

\section{Acknowledgement}

This work was sponsored in part by Carnegie and Ahmadu Bello University, Zaria, Nigeria. We are indeed grateful to them.

\section{References}

Adewummi, C.O., Agbedahunsi, J.M., Adebajo, A.C., Aladesanmi, A.J., Murphy, N., Wando. (2001). Screening of Nigerian medicinal plants for trypanocidal properties. J. Ethnopharm, 77: 19-24.

Anene, B.M, Onah, D.N, Nawa, Y. (2001). Drug resistance in pathogenic African trypanosomes: What hopes for the future? Veterinary Parasitology, 96:83 100.

Atawodi, S.E., Bulus, T., Ibrahim, S., Ameh, D.A.; Nok, A.J., Mamman, M. and Galadima M. (2003). Invitro trypanocidal effect of methanolic extract of some Nigerian Savannah plants. African Journal of Biotechnology, Vol. 2 no. 9. 317- 321.

Camacho, M.D.R., Marley, D., Castaneda, R., Kirby, G.C., Warhurst, D.C., Croft, S.L., Philipson, J.D. (2000b). Bioactivecompounds from Celaenodendron mexicanum. Planta Medica, 66:463-468.

CCAC. (1993). Canadian Council on Animal care Guide Vol. 1 (2 $\left.2^{\text {nd }} E d\right)$.

Cowan, M.M. (1999). Plant products as antimicrobial agents. Clin. Microbiol. Rev., Vol.12. (4) :564-582.

Croft, S.L. (1997). The current status of antiparasitic chemotherapy. Parasitlogy, 114: 3-15.

Freiburghaus, F and Basel, N. (1996). African medicinal plant used in the treatment of sleeping sickness - an evaluation. Weittever service Ag, Bern., Pp 1 -23.

Gutteridge, W.E. (1985). Existing chemotherapy and its limitation. British Med. Bull, 4 (2). 162 - 168.

Hannae, V., Mitchels, P.A.M. (1994). Structure function and biogenesis of glycosomes in kinetoplastidae. Journal of Bioenergetic and Biomembrane, 26: 205-212.

Harborne, J.B. (1973). Phytochemical methods. London Chapman and Hall Ltd. Pp.49-188.

Harborne, J.B., Williams, T.A. (2000). Advances in flavonoid research since 1992. Phytochemistry, 55:81-504.

Herbert, W.J., and Lumsden, W.H.R. (1976). Trypanosoma brucei. A rapid matching method for estimating the host's parasitemia. Experimental Parasitology, 40, 427 - 431.

Hoet, S, Federick, O. Reto, B., Victor, A., Joelle, Q. (2004). In vitro antitrypanosomal activity of ethnopharmacologically selected Beninese plants. Journal of Ethnopharmacology, 91 37-42.

Kaminsky, F., Nkuna, M.H.N. and Brun, R. (1996). Evaluation of African medicinal for their invitro trypanocidal activity. J. Ethnopharm, 55: 1-11.

Kaufman, P.B., Cseke, L.J., Warber, S., Duke, J.A., Brielmann, H.L. (1999). Natural Products from plants. CRC Press, Boca Raton, Fl.

Kayser, O., Kiderlen, A.F., Croft, S.L. (2003). Natural products as potential antiparasitic drugs. Parasitology Research, 90:655-935. 
Kristjanson, P.M., Swallow, B.M., and Rowland, G. (1999). Measuring the cost of African Animal Trypanosomosis, the potential benefits of control and returns and research. Agr. Sys., 59: 79-98.

Maikai, V.A., Salka, M.N., Adeiza, A.A., Makeri, H.K. (2007). Assessment of Isometamidium chloride and diminazene aceturate in laboratory mice infected with field isolates of $\mathrm{T}$. congolense from naturally infected cattle. Journal of Production Agriculture and Technology, 3(1) 147 - 152.

Maikai V.A., Nok, J.A., Adaudi, A.O,. Alawa, C.B.I. (2008a). In vitro antitrypanosomal activity of aqueous and methanolic crude extracts of stem bark of Ximenia americana on Trypanosoma congolense. Journal of medicinal plant Research, Vol. 2(3) pp 055-058.

Maikai V.A. Kobo P.I., Adaudi A.O. (2008b). Acute toxicity studies of aqueous stem bark extract of Ximenia americana. African Journal of Biotechnology, vol.7 (10):1600-1603.

Maikai V.A. (2010). In vitro and in vivo evaluation of anti-trypanosomal activity of stem bark of Ximenia Americana, International Journal of Biology, vol.2(2)pp 50-55.

McDermott, J..J., Sidibe, I., Bauer, B., Diarra, B., Clausen P.H., Woitang, T., Ouedraogo, D., Kamuanga, J.M.B., Peregrine, A.S., Eisler, M.C., Mehlitz, D. (2000). Field studies on the development and impact of drug resistant animal trypanosomes in market oriented production systems in the southern Guinea Zone of West Africa. Newsletter No2 of EU concerted Action on.

Ndung"u, J.M., Murrilla, G.A., Mdachi, R.M., Mbwambo, H., Sinyangwe, L., Machila, N., Delespaux, V., Geerts, S., Brandt, J., Peregrine, A.S., McDermott, J.J., Holmes, P.H., Eisler, M.C. (1999). Area-wide appraisal of drug resistance in trypanosomes infecting cattle in East and Southern Africa. In: Proceedings of the International Scientific council for Trypanosomiasis Research and Control, $25^{\text {th }}$ meeting, Mombasa, Kenya, 27 Sept- ${ }^{\text {st }}$ October 1999. OAU/STRC.Nairobi.

Nok, A.J. (2002). Azaanthraquinone inhibits respiration and in vitro growth of long slender bloodstream forms of T. congolense. Cell Biochemistry and Function, 20: 205-212.

Opperdoes, F.R. (1987). Compartmentation of carbohydrate metabolism in trypanosomes. Annual Review of Micribiology, 41:127-151.

Peter, D; Honigberg, B.M. and Fern, A.M. (1976). An improved method of cryopreservation of Trypanosoma (Nannomonas) Congolense brooden in liquid nitrogen. Journal of Parasitology, 62 (1): 136-137.

Pizzolatti, M.G., Koga, A. H., Grisard, E.C., Steindel, M. (2002). Trypanocidal activity of extracts from Brazilian Atlantic rain forest plant species. Phytomedicine, 9: 422- 426.

Rang, H.P., Dale, M., Ritter, J. (2001). Pharmacology. $4^{\text {th }}$ ed. (USA ed.) New York, Churchill Livingstone.

Raz, B. (1998). Isolation and evaluation of antiparasitic lead compounds from African medicinal plants. PhD Thesis, Universitat Basel.

Sepulaveda-Boza, S.,Cassels, B.K. (1996). Plant metabolite active against Trypanosoma cruzi. Planta med., 62: 98-105.

Sofowora, A. (1993). Medicinal plants and Traditional Medicine in Africa. Spectrum Books Ltd, Ibadan, Nigeria. Pp. 289.

Tarus, P.K., Machocho, A.K., Langat- Thoruwa, C.C., Chhabra, S.C. (2002). Flavonoids from Tephrosia aequilata. Phytochemistry, 60: 375-379.

Tasdemir, D., Kaiser, M., Brun, R., Yardley, V., Schmidt, J.T., Tosun, F., Ruedi, P. (2006). Antitrypanosomal and Antileishmanial activities of flavonoids and their analogues. In vitro, In vivo structure activity relationship studies. Antimicrobial agents and Chemotherapy, 50(4): 1352-1364.

Trease, G.E., Evans, W.C. (1989). Pharmacognosy. $11^{\text {th }}$ Edition Brailliar Trindel Can. Macmillan Publishers.

Tyler, V.E. (1999). Phytomedicines: back to the future. J. Nat. Prod., 62:1589.

Wang Hui-Kang. (2000). The therapeutic potential of Flavonoids. Expert Opinion on Investigational Drugs, 9 (9): 2103-2119.

WHO. (1998). Control and surveillance of African trypanosomosis. World health Organization technical Report Series No. 881 .

WHO. (2000). African trypanosomiasis. In: Report on global surveillance of epidemic prone infectious diseases. WHO/CDS/CSR/ISR/2000.I. 
Williamson, G., Barron, D., Shimoi, K., Terao, J. (2005). In vitro biological properties of flavonoid conjugates found in vivo. Free Radical Research, 39:457-469.

Won S.W., Kuk H.S., Sam S.K. (1980). Chemistry and Pharmacology of Flavone-C-Glycoside from Zizyphus seeds. The Korean Journal of Pharmacognosy, Vol. 11(3-4) 141-148.

Table 1. Phytochemical screening of Ximenia americana

\begin{tabular}{|l|c|c|c|c|c|c|c|c|}
\hline Extract & Alkaloids & Anthraquinones & $\begin{array}{c}\text { Cardiac } \\
\text { glycosides }\end{array}$ & Flavonoids & Pylobatannins & Saponnins & Tannins & Terpenoids \\
\hline $\begin{array}{l}\text { Flavonoid } \\
\text { portion }\end{array}$ & - & - & - & +++ & - & - & - & - \\
\hline $\begin{array}{l}\text { Saponnin } \\
\text { portion }\end{array}$ & - & - & - & - & - & ++ & - & - \\
\hline
\end{tabular}

+++ - highly present, ++ - moderately present, + - faintly present, - absent

Table 2. In vitro effect of crude aqueous and methanolic stem bark extracts of Ximenia americana on $T$. congolense

\begin{tabular}{|c|c|c|c|c|c|c|}
\hline Plant name & $\begin{array}{l}\text { Family } \\
\text { name }\end{array}$ & $\begin{array}{l}\text { Plant } \\
\text { parts } \\
\text { screened }\end{array}$ & $\begin{array}{l}\text { Extract } \\
\text { used }\end{array}$ & $\begin{array}{l}\text { Time taken to } \\
\text { eliminate/immobilize } \\
\text { the parasites }\end{array}$ & $\begin{array}{l}\text { inhibitory } \\
\text { concentration } \\
\text { (IC) }(\mathrm{mg} / \mathrm{ml})\end{array}$ & $\begin{array}{l}\text { Activity on } \\
T . \\
\text { congolense }\end{array}$ \\
\hline \multirow{4}{*}{$\begin{array}{l}\text { Ximenia } \\
\text { americana }\end{array}$} & Olacaceae & Stem bark & Flavonoid & $30 \mathrm{~min}$. & 5 & + \\
\hline & & & Saponnin & $65 \mathrm{~min}$. & 5 & + \\
\hline & & Diminal $^{\mathrm{R}}$ & - & $20 \mathrm{~min}$. & $200 \mu \mathrm{g} / \mathrm{ml}$ & + \\
\hline & & $\begin{array}{l}\text { Control } \\
0.5 \% \\
\text { DMSO }\end{array}$ & - & - & & $\begin{array}{c}\text { Parasites } \\
\text { very active } \\
\text { even after } 2 \\
\text { hours }\end{array}$ \\
\hline
\end{tabular}

$+\quad$ active against $T$. congolense

- not active against $T$. congolense

IC- concentration at which no trypanosome motility was observed when compared to the controls 


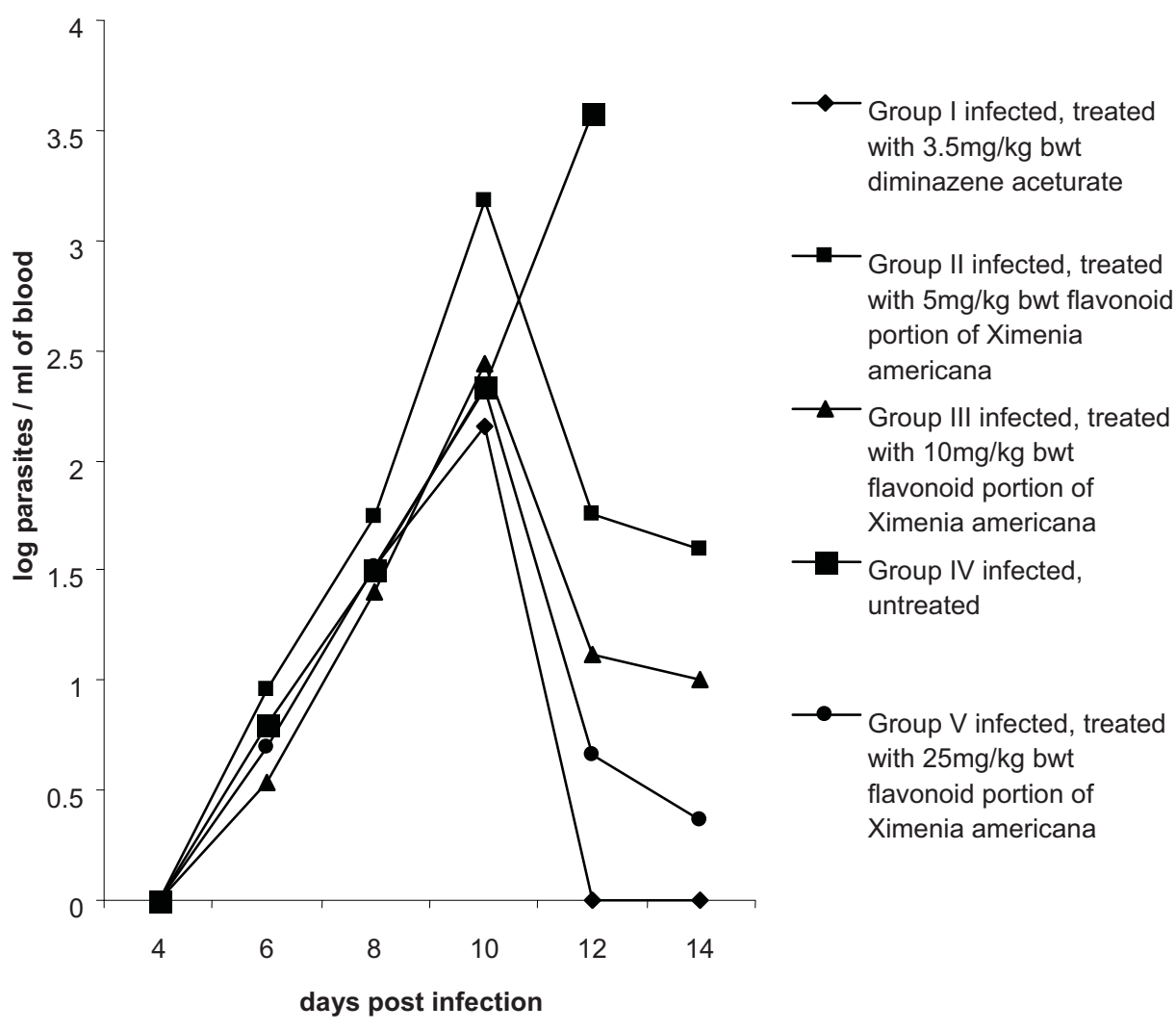

Figure 1. Effect of treatment with different doses of flavonoid extract of Ximenia americana on population of $T$. congolense in mice 